\title{
ICT-tools for internationalization of continuous education
}

\author{
O.V. Lvova \\ Moscow City Pedagogical University \\ 29 Sheremetyevskaya St., Moscow, 127521, Russian Federation
}

\begin{abstract}
Problem and goal. Continuous education is a process of growth of educational (general and professional) potential of the individual throughout life via the use of the system of state and public institutions and in accordance with the needs of the individual and society. The need for continuous education arises due to the progress of science and technology, the widespread use of innovative technologies. Internationalization stands for the intentional process of integrating an international, intercultural or global dimension into the purpose, functions and delivery of education. Information and telecommunication technologies nowadays are a significant part of modern learning and play an important role in continuous education that uses different ICT-tools for its purposes but depending on the interpretation continuing education concept has its own specifics. Accordingly, various procedures for the use of information and telecommunication technologies are in demand. To make the application of ICT-tools for continuous education relevant to the specialized goals one should clearly understand the correlation among aims of continuous learning and ICT-tools.

Methodology. Various procedures for the use of information and telecommunication technologies that are in demand for purposes of internationalization of continuous education are considered. A brief review of scope of ICT-tools and their potential and relevance to the specific aims of internationalization of continuous learning is given.
\end{abstract}

Results. Internationalization of education and development of continuous education are nowadays very important processes all around the world. There are some main trends in application of ICT-tools/ technologies in internationalization of higher education currently being developed and widely used. Mostly all of ICT-tools/technologies can be used in continuous education to solve problems similar to higher education. Meanwhile new ICT-tools/technologies - virtual mobility, distant academic mobility and electronic internationalization - have great potential to be applied for internationalization under specific conditions of continuous education.

Conclusion. It is demonstrated that information and telecommunication technologies supply internationalization of continuous education with not only well known ICT-tools/technologies but also new ones with powerful potential.

Key words: information and telecommunication technologies, internationalization, internationalization at home, continuous education, life-long learning education, adult education, continuing vocational education and training

Problem statement. Continuous education is a process of growth of educational (general and professional) potential of the individual throughout life through the use of the system of state and public institutions and in accordance with the needs of the individual and society. The need for continuous education arises due to the progress of science and technology, the widespread use of innovative technologies. 
Currently, there are different concepts of continuing education:

1. Lifelong learning. Lifelong learning is the "ongoing, voluntary, and self-motivated" [10] pursuit of knowledge for either personal or professional reasons [8; 10; 14].

2. Adult education. Adult education is a practice in which adults engage in systematic and sustained self-educating activities in order to gain new forms of knowledge, skills, attitudes, or values. It can mean any form of learning adults engage in beyond traditional schooling, encompassing basic literacy to personal fulfillment as a lifelong learner [13; $19 ; 21]$.

3. Continuing vocational education and training. Continuing vocational education and training (VET) is a subject within education with different current patterns in different countries [15].

Considering ICT-tools/technologies applied for continuous education one can point out main of them as following:

- application of ICT-tools/technologies for traditional curriculum;

- integration of ICT-tools/technologies in traditional curricula;

- distance learning curricula;

- mass open online courses (MOOC);

- innovative tools/technologies.

Internationalization stands for the intentional process of integrating an international, intercultural or global dimension into the purpose, functions and delivery of postsecondary education, in order to enhance the quality of education and research for all students and staff, and to make a meaningful contribution to society.

Concerning internationalization of higher education (HE) (and to certain extent of continuous education) one can see the following steps:

1994/2015 - Internationalisation of HE (IoHE) (Knight [17]);

1995/1996 - Internationalization of the Curriculum (Bremer \& v.d. Wende [6]);

1996 - Internationalization of the Curriculum (OECD) [20];

2001 - Internationalisation at Home (IaH) (Crowther et al. [9]);

2009/15 - Internationalisation of the Curriculum (IoC) (Leask [18]);

2011 - Comprehensive Internationalization (CI) (Hudzik [16]);

2015 - Internationalisation of HE (updated) (De Wit, Hunter, Coelen [11]);

2015 - Internationalisation at Home (updated) Beelen and Jones [5]);

2016 - Learner-Centred Internationalisation of HE (L-C IoHE) (Coelen [7]).

The process consists of two main trends:

— involvement into international activity;

- systematical integration on international component into education, research and public activity of educational institutions.

It corresponds to Internationalization and Internationalization at Home.

Depending on the interpretation continuing education concept will have its own specifics. Accordingly, various procedures for the use of information and telecommunication technologies will be in demand.

Nowadays main forms of internationalization are:

- student's mobility;

- teacher's mobility;

- internationalization of educational programmes; 
- transnationalization of education;

- harmonization of programmes.

Method of research. Analysis of ICT-tools/technologies applied in internationalization of higher education and investigation of their potential in use for continuous education.

Results and discussion. ICT-tools/technologies are constantly developing conquering new positions in various fields of human activity and becoming one of the important tools for gaining knowledge of the world. It is not surprising that today there is a great need in arranging ICT-tools/technologies application for different fields and aims in learning.

One can say that rapid development of continuous education is possibly mostly due to the use of modern information and telecommunication technologies [2;3].

On the other hand being one of the maintaining factors in international educational cooperation internationalization and internationalization at home are becoming more and more crucial [12]. Currently it provides not only broadening and deepening one's knowledge but also serves as a powerful driver in competition among educational institutions all over the world [4].

It is obvious that ICT-tools/technologies can be applied in internationalization of continuous education in different ways depending on aims, conditions, focus group, means and some factors. The main trends of their application in this field are:

- application of ICT-tools/technologies for traditional curricula;

- integration of ICT-tools/technologies into traditional curricula;

- distant courses;

- mass open online courses (MOOK);

- innovative tools (technologies).

First four points are already well established. There is a lot of literature devoted to scientific research, development, theoretical bias, design, fields of most effective application, relevancy, etc. of the tools and technologies. The author only want to draw attention to the following: one and the same thing is sometimes called tool (means) and sometimes technology. It is not an inaccuracy. It depends on situation. If any opportunity given by ICT is used to reach relevant educational goals it is a tool (means) of education, but if one research the given tool and its potential in details than it becomes a technology. The simplest examples are Word and Power Point.

When we use them to express our thoughts our to present some ideas they are simply tools, but when we start to research their potential and learn to use them more effectively and relevantly to our goals they become a technology. Therefore one can consider ICTtools/technologies from point of view of their relevant and effective application for educational goals or learning how to use them properly and more effectively. The remark is rather important because it points out two different ways teaching (learning) how to apply ICT-tools/technologies. Usually one of the approaches greatly prevails but there cases when such situation is adverse. Balance is the most suitable. The other point very important by itself and somehow connected with the above said is relevancy. Speaking about application of ICT-tools/technologies in internationalization of continuous education one should take into account a lot of factors: accessibility, coincidence with national standards, peculiarities, understandability, tolerance [1], etc. 
Let's consider three innovative ICT-tools/technologies for internationalization of continuous education.

Virtual mobility. Real students' and teachers' mobility has already become an integrative part of internationalization of higher education, nowadays a new type - virtual academic mobility is rather rapidly developing in higher education but continuous education has some peculiarities (e.g. learners cannot afford to leave for a long time or are afraid of going to foreign countries) that do not limit better say transform this type of activity. Virtual mobility is not limited to a certain period of time or space and allows participants to replenish professional portfolio and educational institutions to develop LLL (life-long learning) programmes. Moreover it supports cooperation of different individuals from different cultures or subject areas inside virtual community [22].

Distant academic mobility. It means ability for learners to get educational services online at relevant sites. Nowadays it is used mostly by learners - students (i.e. in higher education). It helps to broaden mind of learners, join them to treasures of world knowledge, look at different events and phenomena from different points of view, feel cultural and national differences and feel themselves part of global community. For sure, students find relevant sites on their own (still sometimes sites are recommended by teachers) but final results of the educational steps are discussed with teachers. This is the main and very important point especially in application for continuous education. The other crucial point is language. Speaking about internationalization we mostly mean English as language of international communication. It results into two trends in development of internationalization of continuous education:

1. Since less learners in continues education than in higher education are good at English special resources to have adequate translation, acquire, master, brush up English.

2. To strengthen competitive positions at the global education market and to increase the attractiveness of national educational institutions abroad and promote their efficiency as exporters of education.

There is a lot of ICT-tools/technologies to reach the first aim. They are well developed and widely described and presented elsewhere.

Electronic internationalization is a new ICT-tool/technology to reach the second aim. It stands for Internet resources of the educational institution in English including sites of the educational institution with relevant information (at least, information about educational institution, history of the institution, admission to the institution, educational programmes of the institution, library, mission and strategic goals of the educational institution, contacts) and accounts of educational institutions in English-speaking social nets.

Conclusion. Great potential of abovementioned ICT-tools/technologies application for internationalization of continuous education will result in significant improvement in this area of activity. However, further theoretical and practical investigations mostly of international scale are in demand.

(C) Lvova O.V., 2019

This work is licensed under a Creative Commons Attribution 4.0 International License 


\section{References}

[1] Grigoryev S.G.. Grinshkun V.V.. Lvova O.V. Ispolzovaniye sredstv informatizatsii dlya formirovaniya tolerantnosti pri obuchenii $\mathrm{v}$ techeniye vsey zhizni [The use of informatization tools for the formation of tolerance in education throughout life]. Vestnik Moskovskogo gorodskogo pedagogicheskogo universiteta. Serija: Informatika i informatizacija obrazovanija [Bulletin of the Moscow City Pedagogical University. Series: Informatics and Informatization of Education]. 2016. No. 1 (35). Pp. 8-19.

[2] Grinshkun V.V. Razvitiye integrativnykh podkhodov k sozdaniyu sredstv informatizatsii obrazovaniya [Development of integrative approaches to the creation of means of informatization of education]. http://www.dissertations/archive/index.php (accessed: 10.10.2018).

[3] Pushkarev Yu.V., Pushkareva E.A. Nepreryvnoye obrazovaniye v sovremennykh usloviyakh: osnovnyye kontseptualnyye podkhody [Lifelong education in modern conditions: the main conceptual approaches]. Vestnik Novosibirskogo gosudarstvennogo pedagogicheskogo universiteta [Bulletin of the Novosibirsk State Pedagogical University]. 2015. No. 6(28). Pp. 161-171.

[4] Filippov V.M. Internatsionalizatsiya vysshego obrazovaniya: osnovnyye tendentsii, problemy i perspektivy [The internationalization of higher education: major trends, problems and prospects]. Vestnik Rossijskogo universiteta druzhby narodov. Serija: Informatizacija obrazovanija [Bulletin of Peoples' Friendship University of Russia. Series: International relations]. 2015. No. 3. Pp. 203-211.

[5] Beelen J., Leask B. Internationalization at home on the move. Berlin: Dr. Josef Raabe Verlag, 2011. $204 \mathrm{p}$.

[6] Bremer L., Van der Wende M. Internationalizing the curriculum in higher education. The Hague: Nuffic, 1995. 74 p.

[7] Coelen R.J. Ranking and the measurement of success in internationalisation: are they related? Amsterdam, 2009. Pp. 39-48.

[8] Commission of the European Communities: adult learning: it is never too late to learn. Brussels, 2006. $89 \mathrm{p}$.

[9] Crowther P., Joris M., Otten M., Nilsson B., Teekens H., Wächter, B. Internationalisation at home: a position paper. Amsterdam: EAIE, 2001. $45 \mathrm{p}$.

[10] Department of Education and Science. Learning for Life: Paper on Adult Education. Dublin: Stationery Office, 2000. 112 p.

[11] De Wit H. Erasmus at 25: What is the future for international student mobility? www.theguardian. com/guardian-professional (accessed: 10.10.2018).

[12] Elspeth J., Jos B., Robert C., de Wit H. Local and Global Internationalisation. Sense Publishers. Dordrecht, 2016. $88 \mathrm{p}$.

[13] Fenwick T., Nesbit T., Spencer B. Contexts of adult education: Canadian perspectives. Toronto: Thompson Educational Publ., 2006. P. 17.

[14] Fischer G. Lifelong Learning - More than Training. Journal of Interactive Learning Research. 2000. Vol. 11. Pp. 265-294.

[15] Grubb N. Vocational Education and Training: Issues for a Thematic Review. OECD. November, 2006. $39 \mathrm{p}$.

[16] Hudzik J. Comprehensive internationalization: from concept to action. Washington: NAFSA, 2011. $231 \mathrm{p}$.

[17] Knight J. Updating the definition of internationalization. International Higher Education. 2003. Pp. 2-3.

[18] Leask B. Using formal and informal curricula to improve interactions between home and international students. Journal of Studies in International Education. 2009. Vol. 13(2). Pp. 205-221.

[19] Merriam Sh., Brockett R. The Profession and Practice of Adult Education: an Introduction. JosseyBass, 2007. P. 7.

[20] Rizvi F. Internationalizing the curriculum in higher education. Paris, 1996. 54 p.

[21] Spencer B. The purposes of adult education: a short introduction. Toronto: Thompson Educational Publ., 2006. Pp. 9-10.

[22] TeaCamp. http://teacamp.vdu.lt/content/about-project-0 (accessed: 10.10.2018). 
Article history:

Received: 05 November 2018

Accepted: 08 December 2018

For citation:

Lvova O.V. (2019). ICT-tools for internationalization of continuous education. RUDN Journal of Informatization in Education, 16(1), 56-63. DOI 10.22363/2312-8631-2019-16-1-56-63

\title{
Bio Note:
}

Lvova Olga Vladimirovna, candidate of pedagogical sciences, docent of the department of informatization of education of Moscow City Pedagogical University. Contact information: e-mail: olglvova@yandex.ru.ru

\section{ИКТ-инструменты для интернационализации непрерывного образования}

\author{
О.В. Львова \\ Московский городской педагогический университет \\ Российская Федерация, 127521, Москва, ул. Шереметьевская ул., 29
}

Проблема и цель. Непрерывное образование представляет собой процесс роста образовательного (общего и профессионального) потенциала личности в течение всей жизни на основе использования системы государственных и общественных институтов в соответствии с потребностями личности и общества. Необходимость непрерывного образования обусловлена прогрессом науки и техники, широким применением инновационных технологий. Под интернационализацией понимают целенаправленный процесс интеграции международного, межкультурного или глобального измерения в цели, функции и обеспечение высшего образования с целью повышения качества образования и научных исследований для всех учащихся и сотрудников и внесения существенного вклада в жизнь общества.

В наши дни информационные и телекоммуникационные технологии являются важной частью современного образовательного процесса и играют значительную роль в непрерывном образовании, обеспечивая его нужды различными ИКТ-инструментами, однако в зависимости от предлагаемого подхода непрерывное образование обладает и определенной спецификой. Соответственно, возникает потребность в различных информационных и телекоммуникационных технологиях и методах их применения. Чтобы эффективно использовать информационные и телекоммуникационные технологии для решения задач непрерывного образования, необходимо четко соотносить цели непрерывного образования и потенциал тех или иных ИКТ-инструментов.

Методология. Рассмотрены различные способы применения информационных и телекоммуникационных технологий для интернационализации непрерывного образования. Проанализирована область применения различных ИКТ-инструментов и возможности их использования для решения задач интернационализации непрерывного образования с учетом специфики этой деятельности.

Результаты. В настоящее время интернационализация образования и развитие непрерывного образования являются важными процессами мирового уровня. При этом в ходе интернационализации высшего образования наблюдается несколько основных тенденций использования хорошо развитых и широко применяемых ИКТ-инструментов/технологий. Большин- 
ство из указанных ИКТ-инструментов/технологий могут быть использованы также и в непрерывном образовании для решения аналогичных задач. При этом новые ИКТ-инструменты/ технологии - виртуальная мобильность, дистанционная академическая мобильность и электронная интернационализация - имеют значительные, однако еще недостаточно используемые возможности для решения задач именно непрерывного образования.

Заключение. Показано, что информационные и телекоммуникационные технологии обеспечивают интернационализацию непрерывного образования не только хорошо известными ИКТ-инструментами/технологиями, но и новыми, обладающими широкими возможностями в этой области.

Ключевые слова: информационные и телекоммуникационные технологии, внешняя интернационализация, внутренняя интернационализация, непрерывное образование, обучение на протяжении всей жизни, образование для взрослых, непрерывное профессиональное образование

\section{Список литературы}

[1] Григорьев С.Г., Гриншкун В.В., Львова О.В. Использование средств информатизации для формирования толерантности при обучении в течение всей жизни // Вестник Московского городского педагогического университета. Серия: Информатика и информатизация образования. 2016. № 1 (35). С. 8-19.

[2] Гриншкун В.В. Развитие интегративных подходов к созданию средств информатизации образования. URL: http://www.dissertations/archive/index.php (дата обращения: 10.10.2018).

[3] Пушкарёв Ю.В., Пушкарёва Е.А. Непрерывное образование в современных условиях: основные концептуальные подходы // Вестник Новосибирского государственного педагогического университета. 2015. № 6 (28). С. 161-171.

[4] Филиппов В.М. Интернационализация высшего образования: основные тенденции, проблемы и перспективы // Вестник Российского университета дружбы народов. Серия: Международные отношения. 2015. № 3. С. 203-211.

[5] Beelen J., Leask B. Internationalization at home on the move. Berlin: Dr. Josef Raabe Verlag, 2011. 204 p.

[6] Bremer L., Van der Wende M. Internationalizing the curriculum in higher education. The Hague: Nuffic, 1995. 74 p.

[7] Coelen R.J. Ranking and the measurement of success in internationalisation: are they related? Amsterdam, 2009. Pp. 39-48.

[8] Commission of the European Communities: adult learning: it is never too late to learn. Brussels, $2006.89 \mathrm{p}$.

[9] Crowther P., Joris M., Otten M., Nilsson B., Teekens H., Wächter, B. Internationalisation at home: a position paper. Amsterdam: EAIE, 2001. 45 p.

[10] Department of Education and Science. Learning for Life: Paper on Adult Education. Dublin: Stationery Office, 2000. 112 p.

[11] De Wit H. Erasmus at 25: What is the future for international student mobility? URL: www. theguardian.com/guardian-professional (дата обращения: 10.10.2018).

[12] Elspeth J., Jos B., Robert C., de Wit H. Local and Global Internationalisation // Sense Publishers. Dordrecht, 2016. $88 \mathrm{p}$.

[13] Fenwick T., Nesbit T., Spencer B. Contexts of adult education: Canadian perspectives. Toronto: Thompson Educational Publ., 2006. P. 17.

[14] Fischer G. Lifelong Learning - More than Training // Journal of Interactive Learning Research. 2000. Vol. 11. Pp. 265-294.

[15] Grubb N. Vocational Education and Training: Issues for a Thematic Review. OECD. November, 2006. 39 p.

[16] Hudzik J. Comprehensive internationalization: from concept to action. Washington: NAFSA, 2011. $231 \mathrm{p}$. 
[17] Knight J. Updating the definition of internationalization // International Higher Education. 2003. Pp. 2-3.

[18] Leask $B$. Using formal and informal curricula to improve interactions between home and international students // Journal of Studies in International Education. 2009. Vol. 13 (2). Pp. 205221.

[19] Merriam Sh., Brockett R. The Profession and Practice of Adult Education: an Introduction. JosseyBass, 2007. P. 7.

[20] Rizvi F. Internationalizing the curriculum in higher education. Paris, 1996.54 p.

[21] Spencer B. The purposes of adult education: a short introduction. Toronto: Thompson Educational Publ., 2006. Pp. 9-10.

[22] TeaCamp. URL: http://teacamp.vdu.lt/content/about-project-0 (дата обращения: 10.10.2018).

\section{История статьи:}

Дата поступления в редакцию: 05 ноября 2018

Дата принятия к печати: 08 декабря 2018

\section{Для цитирования:}

Львова О.В. ICТ-tools for internationalization of continuous education (ИКТ-инструменты для интернационализации непрерывного образования) // Вестник Российского университета дружбы народов. Серия: Информатизация образования. 2019. Т. 16. № 1. С. 56-63. DOI 10.22363/2312-8631-2019-16-1-56-63

\section{Сведения об авторе:}

Львова Ольга Владимировна, кандидат педагогических наук, доцент кафедры информатизации образования Московского городского педагогического университета. Контактная информация: e-mail: olglvova@yandex.ru 